\title{
Algumas propriedades de virulência de Escherichia coli isoladas de pacientes com doença inflamatória intestinal
}

\section{DANYELLE AMÉLIA GRECCO SAMEGIMA}

Dissertação apresentada ao Programa de PósGraduação em Microbiologia do Instituto de Ciências Biomédicas da Universidade de São Paulo, para a obtenção do Título de Mestre em Ciências Biológicas.

Área de concentração: Microbiologia

Orientador: Prof. Doutor Josias Rodrigues.

\section{São Paulo}


DADOS DE CATALOGAÇÃO NA PUBLICAÇÃO (CIP)

Serviço de Biblioteca e Informação Biomédica do

Instituto de Ciências Biomédicas da Universidade de São Paulo

(c) reprodução total

Grecco, Danyelle Amélia Samegima.

Algumas propriedades de virulências de Escherichia coli isoladas de pacientes com doenças inflamatória intestinal / Danyelle Amélia Samegima Grecco,. -- São Paulo, 2008.

Orientador: Josias Rodrigues.

Dissertação (Mestrado) - Universidade de São Paulo. Instituto de Ciências Biomédicas. Departamento de Microbiologia. Área de concentração: Microbiologia. Linha de pesquisa: Pesquisa de fatores de virulência de enteropatógenos.

Versão do título para o inglês: Some virulence properties of Escherichia coli isolated from patients with inflammatory bowel disease.

Descritores: 1. Escherichia Coli 2. Doença 4. Inflamação 5. Intestinal 6. Virulência I. Josias, Rodrigues II. Universidade de São Paulo. Instituto de Ciências Biomédicas. Programa de Pós-Graduação em Microbiologia III. Título. 
UNIVERSIDADE DE SÃO PAULO

INSTITUTO DE CIÊNCIAS BIOMÉDICAS

Candidato(a): $\quad$ Danyelle Amélia Samegima Grecco,.

Título da Dissertação: $\quad$ Algumas propriedades de virul encias de Escherichia coli isoladas de pacientes com doenças inflamatória intestinal .

Orientador(a): Josias Rodrigues.

A Comissão Julgadora dos trabalhos de Defesa da Dissertação de Mestrado, em sessão pública realizada a .................................................,

\section{$\begin{array}{ll}\text { ( ) Aprovado(a) ( ) Reprovado(a) } & \text { (a) }\end{array}$}

Examinador(a): Assinatura:

Nome:

Instituição:

Examinador(a): Assinatura:

Nome:

Instituição:

Presidente: Assinatura:

Nome:

Instituição: 


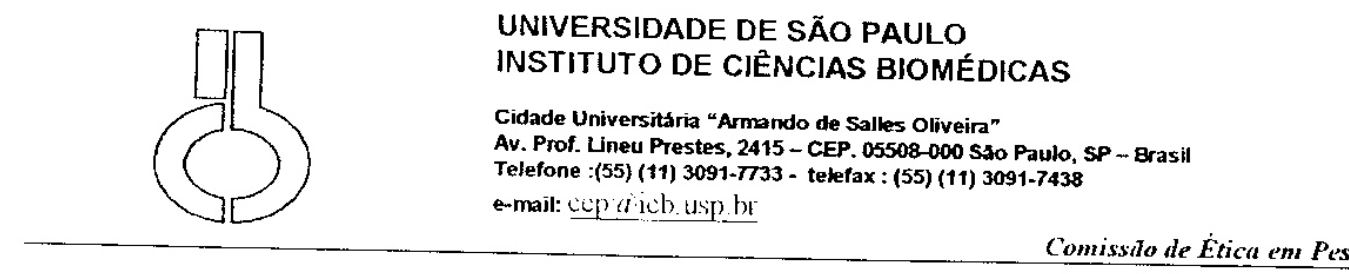

\section{CERTIFICADO DE ISENÇÃO}

Certificamos que o Protocolo CEP-ICB N ${ }^{\circ} 141$, referente ao projeto intitulado "Pesquisa de fatores de virulência de Escherichia coli isoladas de pacientes com doença inflamatória intestinal" sob a responsabilidade de Danyelle Amélia Grecco Samegima, foi analisado na presente data pela CEEA - COMISSÃO DE ÉTICA EM EXPERIMENTAÇÃO ANIMAL e pela CEPSH - COMISSÃO DE ÉTICA EM PESQUiSA COM SERES HUMANOS, tendo sido deliberado que o referido projeto não envolve manipulação animal ou humana que justifique uma aprovação quanto aos princípios éticos exigidos por ambas as Comissões.

São Paulo, 07 de março de 2006.
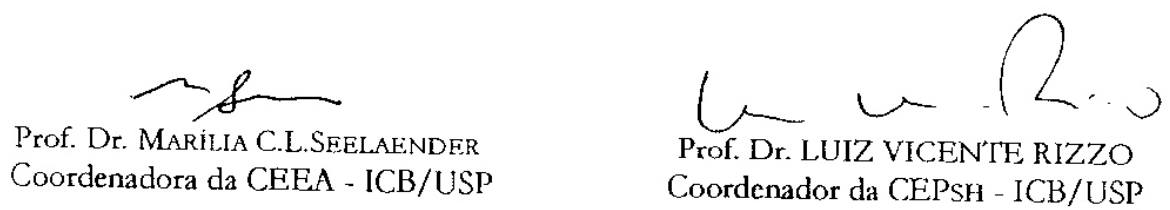


\section{DEDICATÓRIA}

Ao meu marido Harley e filhos Joaquim e Raul, aos meus pais e querida avó, pelo incentivo e apoio constante para a minha formação.

Obrigada!

Amo vocês... 


\section{AGRADECIMENTO ESPECIAL}

Ao Professor e amigo Josias Rodrigues, idealizador deste trabalho e responsável pelo meu ingresso no Curso de Pós-Graduação, por sua brilhante orientação e dedicação, além da constante motivação ao meu aprimoramento pessoal e profissional, pelo respeito as minhas limitações, que não foram poucas, e principalmente pela consideração com que me distinguiu. 


\section{AGRADECIMENTOS}

Ao Laboratório de Microbiologia do Instituto de Biociências de Botucatu, em cujo local foi desenvolvido este trabalho.

A doutoranda Cristiane M. Thomazini e Marisa pelo valioso e inestimável auxílio no desenvolvimento do trabalho.

A amiga e professora Elisete, por sua atenção associada a uma exaustiva paciência em ensinar.

Aos professores Walter Schiller e Luciana Fachin Vicenzi - eternos mestres.

Ao Prof. Doutor Armando Castello Branco Júnior, diretor da Faculdade de Ciências da Saúde da Universidade de Marília, que soube tolerar com paciência, minhas ausências e férias inoportunas.

Aos colegas de trabalho Cirilo, Magno e Angéssima que muito me auxiliaram quando eu precisava viajar, e de certa forma facilitaram minha caminhada.

Em especial aos pacientes que contribuíram para o desenvolvimento deste estudo, sejam eles os portadores de Doença inflamatória intestinal ou não.

Aos queridos amigos e irmãos Ricardo e Amanda Nunes, que mais do que pousada me oferecem apoio e amizade incondicional. Sem vocês eu não teria conseguido.

Aos amigos e professores pela dedicação e incentivo, convívio e amizade.

Enfim a todos que contribuíram para a realização deste trabalho.

Obrigada por tudo! 


\section{RESUMO}

GRECCO, D. A. S. Algumas propriedades de virulência de Escherichia coli isoladas de pacientes com doença inflamatória intestinal. 2008. $52 \mathrm{f}$. Dissertação (Mestrado em Microbiologia) - Instituto de Ciências Biomédicas, Universidade de São Paulo, São Paulo, 2008.

Escherichia coli tem um predomínio anormal em pacientes com doença inflamatória intestinal (DII), mas a razão deste aumento numérico é desconhecida. Amostras de E. coli (131) foram isoladas de biópsias retais de 27 pacientes com retocolite ulcerativa (RU), 8 pacientes com Doença de Chron (DC) e 19 controles. E. coli enteroagregativa (EAEC) foram detectadas no ensaio de adesão de 3 horas a células HEp-2 em $71,4 \%$ dos pacientes com DIl e em $26,3 \%$ dos controles $(P<0,02)$. As cepas de pacientes com DC foram negativas para outros marcadores. Duas cepas invasivas foram detectadas entre pacientes com $\mathrm{RU}$, três deles tinham cepas com plasmídio de adesão agregativa $(p A A)$ e fímbria de adesão agreagativa (aggR) e outras quatro possuíam o gene attaching and effacing (eae). Nenhuma cepa abrigava locus associado à invasão (ial) e antígeno plasmidial de invasão (ipaH). De acordo com esses resultados, EAEC é o grupo dominante encontrado na mucosa colônica de pacientes com DII, mas somente aquelas encontradas em pacientes com RU abrigam marcadores de virulência tradicionais.

Palavras chave: Escherichia coli. Doença inflamatória intestinal. Virulência. 


\begin{abstract}
GRECCO, D. A. S. Some virulence properties of Escherichia coli isolated from patients with inflammatory bowel disease. 2008. $52 \mathrm{f}$. Master thesis (Microbiology) - Instituto de Ciências Biomédicas, Universidade de São Paulo, São Paulo, 2008.
\end{abstract}

Escherichia coli are increased in inflammatory bowel disease (IBD) patients, but the reason for this elevation is unknown. Amongst their properties is the interaction with cultured epithelial cells. Rectal biopsies from 27 ulcerative colitis (UC), 8 Crohn's disease (CD) and 19 control patients were cultured for E. coli, given 131 isolates. Enteroagregative E. coli (EAEC) strains, as detected in $3 \mathrm{~h}$ adherence assays to HEp2 cells, were found in $71.4 \%$ of 35 IBD patients and in $26.3 \%$ of controls $(P<0.02)$. Two highly invasive strains were detected among UC patients, three of whom had also strains with both plasmid of aggregative adhesion ( $\mathrm{pAA}$ ) and aggregative adherence fimbriae $\mathrm{R}(\mathrm{aggR})$ and another four $E$. coli attaching and effacing (eae). No strains had invasion-associated locus (ial) and invasion plasmid antigen $\mathrm{H}(\mathrm{ipaH})$, and those from $C D$ were also negative for other markers. According to these results, EAEC are the dominant E. coli group found in the colonic mucosa of IBD patients, but only those found in UC patients seem to harbor traditional virulence markers.

Key words: Escherichia coli. Inflammatory bowel disease. Virulence. 


\section{LISTA DE ILUSTRAÇÕES}

Figura 1 - Padrões de adesão de Escherichia coli isoladas de pacientes com doença inflamatória intestinal.........................................................................

Figura 2 - Dendrograma da relação genética entre 10 amostras de $E$. coli de diferentes fenótipos de adesão e respectivos padrões de bandas (fingerprints)

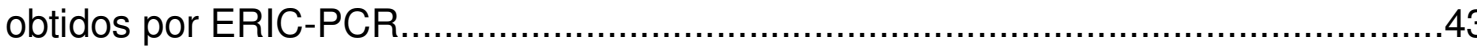

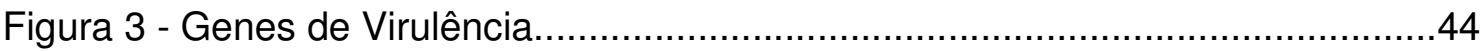

Figura 4 - Invasibilidade das amostras de E. coli isoladas de Pacientes com

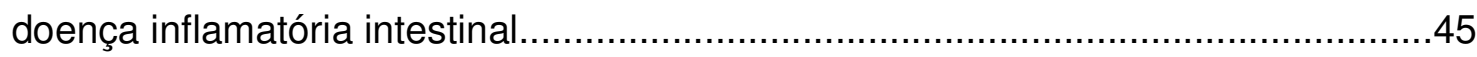




\section{LISTA DE TABELAS}

Tabela 1 - Marcadores genéticos de virulência, primers, tamanho das seqüências amplificadas e condições da PCR

Tabela 2 - Número (\%) de indivíduos nos quais foram isoladas amostras não de $E$. coli aderentes (NA) e amostras apresentando padrões ou fenótipos de adesão típícos a células HEp-2 ........................................................... 


\section{LISTA DE ABREVIATURAS E SIGLAS}

$\mathrm{A} / \mathrm{E}$ - "attaching and effacing"

AA - adesão agregativa

$A D$ - adesão difusa

aggR -"aggregative adherence $\mathrm{R}$ "

ANCA - "antineutrophil cytoplasmatic antibody"

DC - Doença de Crohn

DII - Doença inflamatória intestinal

eae - "E. coli attaching and effacing"

EAEC - E. coli enteroagregativa

EHEC - E. coli enterohemorrágica

EIEC - E. coli enteroinvasora

EPEC - E. coli enteropatogênica

ERIC - "Ennterobacterial repetitive intergenic consensus"

ETEC - E. coli enterotoxigênica

ial - "invasion associated locus"

ipaH - “invasion plasmid antigen $\mathrm{H}$ ”

NA - não aderente

pAA - plasmídio de a adesão aggregativa

RU - Retocolite ulcerativa 


\section{SUMÁRIO}

1INTRODUÇÃO e REVISÃO DE LITERATURA ............................................ 14

1.1 Doença Inflamatória Intestinal ....................................................... 14

1.2 Envolvimento bacteriano com a DII ...................................................... 17

1.3 Doença Inflamatória Intestinal e E. coli............................................... 18

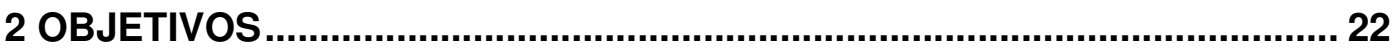

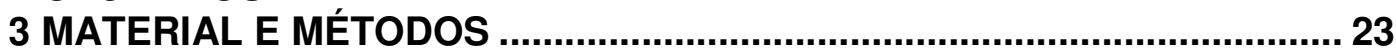

3.1 Indivíduos

3.2 Coleta da biópsia e isolamento de E. coli ............................................. 23

3.3 Determinação de sorogrupos 0 clássicos.............................................. 24

3.4 Produção de Hemolisina.......................................................................... 24

3.5 Cultivo e manutenção das células HEp-2 .............................................. 24

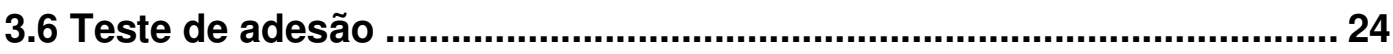

3.7 Cepas bacterianas utilizadas como controles ...................................... 25

3.8 Preparo das monocamadas de células para o teste de invasão........... 25

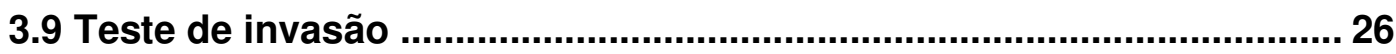

3.10 Preparo de lisados bacterianos para as reações de PCR.................... 26

3.11 Tipagem por ERIC2-PCR..................................................................... 26

3.12 Detecção de marcadores genéticos de virulência .............................. 27

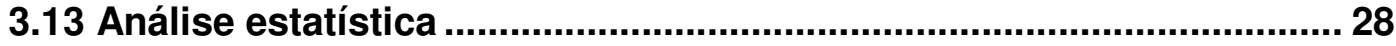

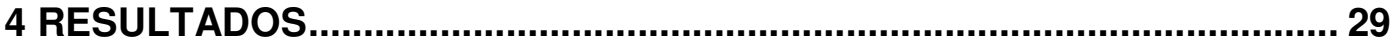

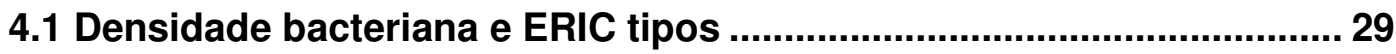

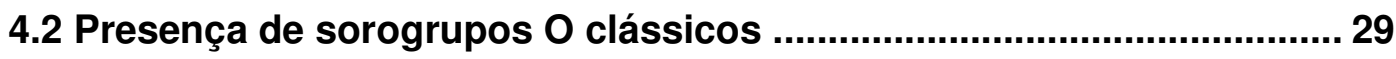

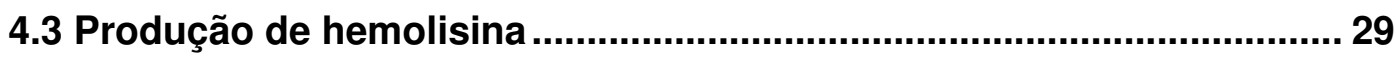

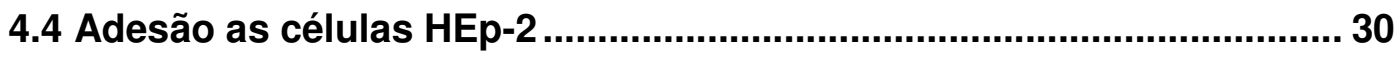

4.5 Relação genética entre amostras aderentes e não aderentes ............. 30

4.6 Marcadores genéticos de virulência........................................................ 30

5 DISCUSSÃO

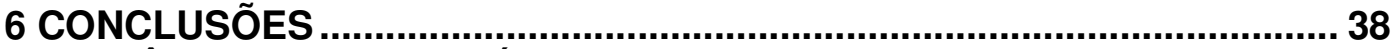

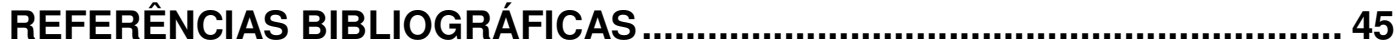




\section{INTRODUÇÃO}

\subsection{Doença Inflamatória Intestinal}

O termo doença inflamatória intestinal (DII) refere-se a manifestações crônicas idiopáticas no trato digestório, de causas não totalmente conhecidas. Sintomas mais freqüentes incluem diarréia, dor abdominal, cólica com náuseas e vômitos, febre moderada, sensação de distenção abdominal que piora com as refeições, perda de peso, mal-estar geral e cansaço. A doença altera períodos sem qualquer sintoma com exacerbações de início e duração imprevisíveis (HENDRICKSON; GOKHALE; CHO, 2002; STROBER; FUSS; MANNON, 2007). Embora, na maioria dos casos, os sintomas sejam tipicamente intestinais, outros tecidos podem ser afetados (HENDRICKSON; GOKHALE; CHO, 2002). Atualmente são reconhecidas duas variantes clínicas da DII: a doença de Crohn (DC) e a retocolite ulcerativa $(\mathrm{RU})$

A doença de Crohn (DC) caracteriza-se por uma inflamação transmural assimétrica, com a presença de granulomas sem caseação, que afeta qualquer porção do trato gastrointestinal, embora o íleo e o cólon direito sejam mais acometidos (HENDRICKSON; GOKHALE; CHO, 2002). As áreas afetadas podem sofrer fistulações, que podem ocorrer isoladamente ou em associação com outras doenças, expondo o indivíduo a infecções recorrentes (STROBER; FUSS; MANNON, 2007). Eventualmente, pode haver complicações mais graves tais como abscessos abdominais, obstrução intestinal e câncer de cólon.

A retocolite ulcerativa $(R U)$ engloba um espectro de inflamação difusa, contínua e superficial que resulta em edema, ulcerações e hemorragia. Esta inflamação é limitada apenas ao cólon e reto, e normalmente começa no reto e se estende até um nível proximal variável (HENDRICKSON; GOKHALE; CHO, 2002; STROBER; FUSS; MANNON, 2007). A principal manifestação clínica é a diarréia com sangue, muco e pus que, conforme a gravidade da doença, pode levar à anemia. Outros sintomas, como febre, mal-estar geral, fraqueza, cólicas e dores abdominais podem estar presentes. Necessidade imediata ou urgência de evacuar, 
perda do controle esfincteriano e dor evacuatória ocorrem devido à inflamação do reto. Quando a doença é intensa, além da anemia e perda de peso pode ocorrer edema nos pés e pernas, desnutrição grave e desidratação.

Indivíduos de qualquer sexo ou faixa etária podem ser acometidos por ambas as manifestações. Porém, uma maior prevalência em indivíduos com idade entre 30 e 40 anos tem sido observada. Embora ocorra em todo o mundo, a Dll é mais comum em alguns países desenvolvidos (ANDUS e GROSS, 2000; WHELAN, 1990). Apesar dos muitos trabalhos conduzidos até então a etiologia da DIl é ainda pouco conhecida (ANDUS e GROSS, 2000; HENDRICKSON; GOKHALE; CHO, 2002). Há, no entanto, um consenso entre a comunidade científica de que a doença não possui uma única causa (ANDUS e GROSS, 2000; FIOCCHI, 2005; HENDRICKSON; GOKHALE; CHO, 2002). Fatores genéticos, imunológicos e ambientais interagem de um modo muito complexo, levando à reação inflamatória exacerbada (FIOCCHI, 2005) responsável pelos sintomas observados.

As alterações genéticas são poligênicas, o que explica as alterações imunológicas e variedade de padrões clínicos encontrados na DII (LAKATOS et al., 2006). Estudos epidemiológicos têm demonstrado que a genética familiar tem um papel fundamental. Cerca de $20 \%$ das crianças afetadas pela doença possuem um histórico familiar de DII. Estudos do genoma humano mostraram a participação de alguns genes como NOD2/CARD15 na DC (NEWMAN e SIMINOVITCH, 2005) e PPAR-y na RU (ARULAMPALAM; GREICIUS; PETTERSSON, 2006), ambos codificando receptores nucleares envolvidos em uma variedade de processos fisiológicos, entre eles o reconhecimento de componentes bacterianos comuns, participando, assim, da resposta imune inata (STROBER; FUSS; MANNON, 2007). NOD2/CARD15 é um receptor intracelular responsável pelo reconhecimento indireto de peptideoglicano. Possui especial função contra bactérias de vida intracelular, e é expresso por várias células como monócitos, células dendríticas, células de Paneth e células epiteliais intestinais (BARNICH e DARFEUILLE-MICHAUD, 2007; LAKATOS et al., 2006). Sua ativação culmina com o desencadeamento de reações pró-inflamatórias, sendo sua expressão regulada positivamente pelo TNF- $\alpha$. Outra função atribuída a estas moléculas é a regulação da degranulação das defensinas produzidas pelas células de Paneth. As defensinas são partes integrantes do 
sistema imune intestinal e atuam como proteínas antimicrobianas endógenas (HOOPER, 2004). Portadores de variantes NOD2/CARD15 podem ter estas funções prejudicadas e serem incapazes de controlar infecções bacterianas, principalmente as relacionadas a patógenos de vida intracelular (BARNICH e DARFEUILLEMICHAUD, 2007).

PPAR- $\gamma$ é um receptor que modula, entre outras funções, a resposta antiinflamatória através da inibição da produção de citocinas pró-inflamatórias em macrófagos/monócitos e células epiteliais, sendo seus níveis regulados pela microflora. Em pacientes com RU, com variantes de $P P A R-\gamma$, os níveis destes receptores no cólon estão prejudicados (ARULAMPALAM; GREICIUS; PETTERSSON, 2006). A adaptação evolutiva dos receptores nucleares, que agem simultaneamente como detectores do ambiente extracelular e mediadores da resposta fisiológica, é certamente importante na regulação da homeostase intestinal, e esta será prejudicada se houver um desequilíbrio na expressão destes receptores (LAKATOS et al., 2006). Todas estas alterações, no entanto, apenas criam um ambiente intestinal favorável ao surgimento da DII, mas não têm um papel direto no desenvolvimento desta, já que menos da metade dos pacientes possuem estas mutações gênicas e cerca de 10 a $20 \%$ da população normal caucasiana as possuem (NEWMAN e SIMINOVITCH, 2005; STROBER; FUSS; MANNON, 2007).

A explicação mais aceita para os sintomas defende que o responsável pela inflamação crônica e patológica observada na DIl é uma resposta imunológica anormal, geneticamente determinada (HENDRICKSON; GOKHALE; CHO, 2002). O que também cria um ambiente favorável ao desenvolvimento da DII, é que tanto a RU como a DC são caracterizadas pelo aumento geral da expressão de citocinas pró-inflamatórias como TNF- $\alpha, \mathrm{IL}-1, \mathrm{IL}-6$ e IL-13. Já a falta de citocinas antiinflamatórias (IL-4, IL-5, IL-10) parece ter um papel muito restrito na doença, sugerido pelo seu baixo potencial terapêutico (LAKATOS et al., 2006).

Dos muitos fatores ambientais estudados como fumo, uso de contraceptivos orais, infecções da infância, consumo de açúcar refinado entre outros, nenhum se mostrou comprovadamente como única causa da DII (ANDUS e GROSS, 2000). Estudos com modelos animais têm demonstrado a importância da microbiota 
intestinal no desenvolvimento e perpetuação da doença, já que esta não pode ser induzida em animais germ free (CAMPIERI e GIONCHETTI, 2001; HART et al., 2002). Porém, o exato papel dos fatores microbianos não está claro. Não se sabe se há uma alteração na microbiota com a presença de linhagens patogênicas (BARNICH e DARFEUILLE-MICHAUD, 2007) ou uma alteração no nível de tolerância a cepas comensais, sendo a última hipótese a mais aceita (GUARNER, 2005; LAKATOS et al., 2006). Em geral, não existe um padrão no tratamento da DII, sendo este individualizado de acordo com as manifestações apresentadas. Como ainda não há cura, o objetivo do tratamento é o controle dos sintomas e das complicações e manutenção dos períodos de remissão (GORDON; SABATINO; MACDONALD, 2005; MONTEIRO, 2005).

\subsection{Envolvimento bacteriano com a DII}

A microbiota intestinal é um vasto ecossistema que conta com mais de 400 espécies bacterianas de aproximadamente 30 gêneros diferentes e outros microrganismos. É extremamente complexa e pode até ser considerada como um órgão funcionalmente ativo, com um potencial metabólico ainda não totalmente conhecido (HOOPER, 2004; NOVERR e HUFFNAGLE, 2004). Mudanças na composição da microbiota, com aumento de algumas espécies bacterianas, particularmente aeróbios facultativos, e redução de alguns anaeróbios estritos e microaerófilos, como Bifidobacterium e Lactobacillus spp, têm sido observadas em portadores de DII (BARNICH e DARFEUILLE-MICHAUD, 2007; GUARNER, 2005; MYLONAKI et al., 2005). Em alguns casos, a elevação da população bacteriana é acompanhada por um aumento na imunoreatividade específcia a seus antígenos (MATSUDA; FUGIYAMA; ANDOH, 2000; SITARMAN et al., 2005). Em portadores de DC esta imunoreatividade aumentada parece ser facilitada por um aumento na permeabilidade da mucosa intestinal, conseqüência de um desequilíbrio na formação do complexo de moléculas que medeiam a adesão célula-célula e célulamatrix extracelular (LAKATOS et al., 2006; SITARMAN et al., 2005).

Entre as bactérias associadas à mucosa, além de $B$. fragilis e $B$. vulgatus, $E$. coli também tem sido encontrada em maior número em pacientes com DII. Há autores que relatam o predomínio anormal desta espécie sobre o número total de aeróbios e anaeróbios em lesões precoces de pacientes com DC (MASSERET et al., 
2001). Estudos sobre a presença de fatores de virulência nestas bactérias apresentam resultados diferentes. Embora a maioria dos trabalhos sugira que sejam membros da microbiota residente, alguns autores têm encontrado variação significativa na presença de fatores de virulência em cepas isoladas de pacientes com DIl e de casos. Darfeuille-Michaud et al.. (1998) demonstraram que lesões de pacientes com DC apresentam grande número de $E$. coli em que não se detectou nenhum fator de virulência típico de amostras patogênicas. Em estudo subseqüente, porém, estes mesmos autores verificaram que uma destas cepas apresentava uma grande capacidade de aderência e invasão frente a diversos tipos celulares (BOUDEAU et al., 1999).

\subsection{Doença Inflamatória Intestinal e E. coli}

E. coli exerce inúmeros papéis benéficos ao organismo, como síntese de vitaminas e competição por espaço e nutrientes com bactérias patogênicas, evitando seu estabelecimento no intestino. Sob condições normais esta espécie não é patogênica e limita-se a sítios intestinais, causando doenças apenas quando defesas naturais são comprometidas. Entretanto, além das linhagens indígenas intestinais há grupos francamente patogênicos que são dotados de fatores de virulência específicos, e são encontrados no trato gastrintestinal transitoriamente. $E$. coli de diferentes categorias patogênicas, assim como as indígenas oportunistas, são capazes de provocar um amplo espectro de infecções, variando de meningite a infecções entéricas (KAPER; NATARO; MOBLEY, 2004; NATARO e KAPER, 1998).

Como aeróbio facultativo dominante da microbiota intestinal, E. coli tem sido o foco natural de estudos para investigar uma suposta origem infecciosa para DII (COOKE et al., 1974). A atenção a estas bactérias se tornou crescente a partir da descoberta de que seu número é aumentado em portadores da doença (KOTLOWSKI et al., 2007; SEKSIK et al., 2003). No entanto, dado à versatilidade da interação da espécie com o homem, não está claro, se o número excedente de $E$. coli compreende cepas da microbiota residente ou inclui clones possuindo marcadores de patogenicidade, que contribuem para os sintomas da DII. Curiosamente, há um clássico exemplo de uma cepa de E. coli com atividade probiótica no controle da DII. Trata-se da Nissle 1917, designada com o nome da cidade egípcia onde foi isolada e o ano do isolamento. Em experimentos 
conduzidos por Kruis et al. (2004), a administração da Nissle 1917 a pacientes com $\mathrm{RU}$ obteve efeito equivalente ao da droga sulfasalazina, utilizada regularmente no tratamento da doença.

Quando comparados com grupos controles, observa-se que pacientes com DII apresentam maiores títulos de anticorpos aglutinantes dirigidos a uma diversidade de antígenos $O$ de $E$. coli. Também tem sido descrito pelo menos um tipo de porina de E. coli apresentando reatividade cruzada com anticorpos anticitoplasma de neutrófilos (ANCA). ANCA, que são auto-anticorpos resultantes da resposta imune anormal, têm sido considerados marcadores sorológicos para o diagnóstico de DII (JASKOWSKI; LITWIN; HILL, 2006). E. coli e outros membros comuns da microbiota residente, como Bifidobacterium e Bacterioides também estimulam a proliferação de clones específicos de células $T$ em pacientes com a doença (DUCHMANN et al., 1999).

O envolvimento de $E$. coli e outras bactérias da microbiota intestinal com a DII pode também ser sugerido pela coincidência dos sítios de lesões e localização da microbiota intestinal (GIONCHETTI; RIZZELO; CAMPIERI, 2001). Não somente as ulcerações são mais numerosas, mas as alterações patológicas são mais intensas em sítios do cólon onde a densidade bacteriana é maior. Nos procedimentos de lavagem intestinal ou administração de drogas antibacterianas a pacientes com DC, os sintomas parecem regredir com a diminuição do nível luminal de bactérias (BARNICH e DARFEUILLE-MICHAUD, 2007).

Diferentes patotipos de $E$. coli diarreiogênicas causam sintomas entéricos muito particulares, que são intimamente relacionados com suas estratégias de virulência (NATARO e KAPER, 1998). Por exemplo, E. coli enterotoxigênica (ETEC) causa diarréia aquosa por excretar toxinas que interferem com mecanismos regulatórios da guanilase e adenilase ciclase, resultando em um desequilíbrio hidro salino; todavia não provocam qualquer alteração patológica. $E$. coli enteropatogênica (EPEC) não produz exotoxinas, mas induz profundas lesões ultramicroscópicas na célula hospedeira, o que compromete a capacidade de absorção pelo intestino. E. coli enteroinvasora (EIEC) invade as células mucosas destruindo-as, levando a uma reação inflamatória que é responsável pelos sintomas típicos de disenteria (KAPER; NATARO; MOBLEY, 2004). 
Ao contrário dos últimos exemplos, a maioria das ETEC é incapaz de aderir a células epiteliais de cultura. Elas aderem somente superficialmente ao enterócitos e atuam através do comprometimento da fisiologia normal da célula. EPEC e EIEC são especializadas em uma associação mais íntima com a célula hospedeira. As duas interferem com a arquitetura do citoesqueleto dos enterócitos, usando estratégias distintas. EPEC se fixa diretamente ao enterócito formando microcolônias que causam lesões ultraestruturais conhecidas como "attaching and effacing" (A/E). Essa lesão é marcada pela associação íntima da bactéria com enterócito, destruição das microvilosidades e formação de estruturas que "lembram" pedestais, onde se situam as bactérias. A intimina é a proteína bacteriana, codificada pelo gene eae, responsável pela aderência íntima às células hospedeiras. O receptor da intimina, denominado Tir ("translocated intimin receptor"), é produzido pela bactéria e inserido na célula hospedeira durante a infecção. Os genes envolvidos na formação da lesão $A / E$ estão localizados em uma ilha de patogenicidade denominada "locus of enterocyte effacement" (LEE). Já EIEC entram nas células $M$ e são fagocitadas por macrófagos subjacentes, em seguida lisam os macrófagos e entram nas células da mucosa pela superfície basolateral (NATARO e KAPER, 1998).

Outro patotipo diarreiogênico corresponde a $E$. coli enteroagregativas (EAEC), que pode ser especialmente importante porque estão epidemiologicamente associadas com diarréia persistente em crianças e adultos, principalmente de países em desenvolvimento (NATARO e KAPER, 1998). EAEC aderem fortemente a células HEp-2 e HeLa, em arranjos que assemelha-se a tijolos empilhados, num padrão referido como agregativo $(A A)$. Este fenótipo tem sido atribuído à presença das fímbrias de aderência agregativa do tipo I e II (AAF I/II) (KAPER; NATARO; MOBLEY, 2004) e outras adesinas ainda não descritas. Os genes responsáveis pela expressão destas fimbrias estão presentes em regiões distintas de um plasmídeo de $60 \mathrm{MDa}$ conhecido como pAA (plasmídeo de adesão a gregativa). Uma destas regiões codifica, entre outras proteínas, um regulador transcricional de genes de virulência denominado AggR (NATARO; MOBLEY, 2004). Quanto à patogênese, EAEC caracteristicamente induzem um aumento na secreção de muco, sob o qual as bactérias ficam protegidas formando um biofilme que impede a 
absorção de nutrientes e promove a colonização persistente do intestino (KAPER; NATARO; MOBLEY, 2004).

Vários estudos têm levantado uma hipótese de que $E$. coli aderentes ou virulentas contribuem para a patogênese da DII (BARNICH e DARFEUILLEMICHAUD, 2007). Em trabalho realizado com 74 pacientes portadores de DII, Giaffer; Holdsworth e Duerden (1992), observaram diferenças significativas na capacidade de adesão a células epiteliais entre bactérias isoladas de pacientes e de indivíduos normais. Estes autores encontraram E. coli aderentes em $62 \%$ de pacientes com DC, $68 \%$ de pacientes com RU e em somente $6 \%$ de indivíduos normais. Além da propriedade de adesão, tem sido também demonstrado que $E$. coli isoladas de pacientes com DIl têm uma maior capacidade de digerir mucina (VAN DER WIEL-KORSTANJE e WINKLER, 1975) e de produzir enterotoxinas (COOKE et al., 1974). 


\section{OBJETIVOS}

Proceder à caracterização de amostras de $E$. coli isoladas de portadores de DIl e de indivíduos não portadores da doença, através de:

a) Sorotipagem e tipagem por "Ennterobacterial repetitive intergenic consensus" (ERIC-PCR);

b) Pesquisa de alguns genes de virulência (eae, ial, ipaH aggR e pAA);

c) Teste de adesão e invasão a células HEp-2. 


\section{MATERIAIS E MÉTODOS}

\subsection{Indivíduos}

Consistiram de 54 adultos atendidos na Unidade de Gastroenterologia do Hospital das Clínicas da UNESP de Botucatu, para colonoscopia de rotina. Trinta e cinco pacientes (16 homens e 19 mulheres) foram diagnosticados com DIl em diferentes estágios de atividade (moderada ou intensa, segundo avaliação clínica), 8 do quais com DC e $27 \mathrm{com} R U$. Os 19 restantes (8 homens e 11 mulheres) apresentavam outras patologias como por exemplo câncer coloretal e compreenderam o grupo controle. Os pacientes com DII tinham idade que variava de 20 a 77 anos e o grupo controle entre 38 a 82 anos. Exceto sulfasalazina, rotineiramente administrada a pacientes com DII, nenhuma outra droga havia sido administrada aos pacientes incluídos no estudo.

Todos os procedimentos relativos ao manuseio e coleta das biópsias dos pacientes seguiram as normas definidas pelo Comitê de Ética Experimental com Seres Humanos da Faculdade de Medicina da UNESP de Botucatu. Após ser informado da proposta do estudo, cada paciente assinou um termo de consentimento Livre e Esclarecido, concordando em participar do estudo.

\subsection{Coleta da biópsia e isolamento de E. coli}

As biópsias consistiram de um número de dois a três fragmentos de tecido epitelial, ca. $2 \mathrm{~mm}$, coletados de áreas lesionadas e distintas da mucosa do cólon, que foram dispensados em volumes de $3 \mathrm{ml}$ de salina glicerina (30\% de glicerol em PBS, pH 7,4) onde permaneceram a $4{ }^{\circ} \mathrm{C}$ por até duas horas antes do isolamento bacteriano. $\mathrm{O}$ isolamento bacteriano foi feito pela semeadura direta dos fragmentos de tecido em placas de ágar MacConkey (Biobrás, Brasil), que foram incubadas a 37 ${ }^{\circ} \mathrm{C}$ por 18-24 horas. Após o crescimento, um número de 2 a 5 colônias foram isoladas de cada paciente e então submetidas a identificação bioquímica utilizando os seguintes meios: EPM, MILI (Probac do Brasil S/A) e citrato (Oxoid, Inglaterra), seguindo procedimentos bacteriológicos convencionais. Colônias identificadas como E. coli foram cultivadas e estocadas em ágar inclinado e posteriormente em TSB 
(Biobrás). Culturas em TSB foram acrescidas de 15\% de glicerol e armazenadas a $80 \stackrel{\circ}{\circ}$.

\subsection{Determinação de sorogrupos 0 clássicos}

A determinação de sorogrupos $O$ clássicos foi realizada através de reações de aglutinação em lâminas de vidro. A partir de culturas jovens crescidas em ágar nutriente inclinado (Oxoid), foi transferida assepticamente uma massa de crescimento bacteriano para lâminas de vidro limpas, em seguida foram acrescentados os soros e observada a ocorrência de um precipitado branco, que indicava um resultado positivo. As amostras foram inicialmente testadas com soros polivalentes A, B e C (Probac) e, em seguida, com soros monovalentes específicos para os antígenos O clássicos de EPEC. (WORLD HEALTH ORGANIZATION , 1987).

\subsection{Produção de Hemolisina}

Para detecção da produção de hemolisina, as bactérias foram semeadas superficialmente e em profundidade em ágar base (Oxoid) enriquecido com $5 \%$ de sangue de carneiro desfibrinado, e mantidas a $37{ }^{\circ} \mathrm{C}$ por 18 a 24 horas. Foram consideradas amostras positivas aquelas capazes de produzir um halo de hemólise total ao redor do crescimento bacteriano.

\subsection{Cultivo e manutenção das células HEp-2}

Para obtenção de monocamada celular, células HEp-2 foram cultivadas em garrafas de poliestireno com área de $25 \mathrm{~cm}^{2}$, contendo $10 \mathrm{ml}$ de meio de Eagle (Sigma, St Louis, MO, EUA) e 10\% de soro fetal bovino (MEM/SFB) e mantidas em estufa a $37{ }^{\circ} \mathrm{C}$ com atmosfera de $5 \%$ de $\mathrm{CO}_{2}$, através de repiques sucessivos realizados periodicamente.

\subsection{Teste de adesão}

Para o teste de adesão, as células foram transferidas, em suspensões de $10^{5}$ células (em MEM/SFB), para poços de microplacas (Nalge Nunc, Rochester NY, EUA), contendo lamínulas esféricas e incubadas por aproximadamente 24 horas. $O$ 
meio de cultura foi desprezado das câmaras e as células foram lavadas com PBS de 3 a 4 vezes. Volumes entre 0,7 e 1,0 $\mathrm{ml}$ de MEM/SFB com 1\% de D-manose foram acrescentados. Em seguida, $20 \mu \mathrm{l}$ de cultura bacteriana (crescimento de 18 horas em meio de TSB) foram inoculados em cada câmara, que foram mantidas por 3 horas em estufa a $37^{\circ} \mathrm{C}$ com $5 \%$ de $\mathrm{CO}_{2}$. Decorrido este período, o meio de cultura foi desprezado, a monocamada lavada com PBS e fixada com metanol (Synth, Brasil) por no mínimo 30 minutos. Em seguida, foram feitas às colorações com MayGrünwald e Giemsa, e as lamínulas foram aderidas a lâminas e feita a observação em microscópio óptico. As amostras bacterianas que não aderiram em $3 \mathrm{~h}$ de incubação, foram submetidas ao mesmo teste num período adicional de 6 horas.

\subsection{Cepas bacterianas utilizadas como controles}

As cepas de referência 17-2 (EAEC) e E-2348/69 (EPEC típica) foram utilizadas como controles positivos no teste de adesão e nas reações de PCR para pAA e eae, respectivamente. As cepas O42 (EAEC) e uma cepa padrão de EIEC foram utilizadas como controle positivos para aggR e ipaH/ial, respectivamente. Esta última foi também utilizada como referência no teste de invasão. Como controle negativo para todos os testes acima, foi utilizada a cepa K12 HB101. Com exceção da cepa de EIEC, prontamente fornecida pela Dra. M. B. Martinez da FCFUSP, todas as demais foram gentilmente cedidas pelo saudoso professor Dr. L. R. Trabulsi do Laboratório Especial de Microbiologia do Instituto Butantã. Estas culturas de referência foram mantidas em caldo BHI (Biobrás), acrescidos de 15\% de glicerol a $-70{ }^{\circ} \mathrm{C}$.

\subsection{Preparo das monocamadas de células para o teste de invasão}

O teste de invasão foi realizado utilizando células HEp-2 mantidas em cultura, do mesmo modo que as empregadas no teste de adesão. Cerca de $20 \mathrm{~h}$ antes do teste, $1 \mathrm{ml}$ de suspensão em meio de Eagle sem antibiótico, contendo $4 \times 10^{5}$ células foi transferido para pocinhos de placas de cultura (Nalge) que foram incubados em estufa a $37 \stackrel{\circ}{\mathrm{C}}$ em atmosfera com $5 \%$ de $\mathrm{CO}_{2}$. 


\subsection{Teste de invasão}

As monocamadas celulares foram inicialmente lavadas 3x com PBS $(\mathrm{pH} 7,2)$. Em seguida foram acrescentadas as amostras bacterianas, numa proporção de 100 bactérias para cada célula HEp-2. As preparações foram incubadas por $2 \mathrm{~h}$ a $37{ }^{\circ} \mathrm{C}$ em estufa com atmosfera de $\mathrm{CO}_{2}$ e lavadas 4x com PBS. Em seguida, foram acrescentados $1 \mathrm{ml}$ de meio de Eagle, contendo $100 \mu \mathrm{g} / \mathrm{ml}$ de gentamicina (Bayer, Alemanha) e as preparações foram incubadas por um período adicional de uma hora em iguais condições. As monocamadas foram novamente lavadas por $6 \mathrm{x}$ e as células lisadas, com $1 \mathrm{ml}$ de Triton-X 100 (Sigma) a 1\% em água deionizada estéril. Os lisados foram plaqueados em ágar nutriente para se quantificar as bactérias intracelulares (que sobreviveram ao tratamento com gentamicina). A invasibilidade foi expressa em termos de porcentagem de bactérias do inóculo inicial que estiveram presentes nos lisados.

\subsection{Preparo de lisados bacterianos para as reações de PCR}

Volumes de aproximadamente $1 \mathrm{ml}$ de cultura bacteriana, de 1 noite em caldo Lúria, foram centrifugados em tubos de polipropileno de $1,5 \mathrm{ml}$, até formação do sedimento. $\mathrm{O}$ sobrenadante foi descartado e o sedimento ressuspenso em $1 \mathrm{ml}$ de água destilada. A suspensão foi fervida por aproximadamente 10 minutos em banho-maria, resfriada e imediatamente colocada em banho de gelo para evitar a renaturação do DNA.

\subsection{Tipagem por ERIC2-PCR}

Preparo da mistura máster: Num tubo de polipropileno de 0,6 $\mathrm{ml}$, foram acrescentados 25 pmoles do primer ERIC2 (IDT), 1,25 mM de dNTP (Promega), 2 unidades de TaqDNA polimerase (Promega), $5 \mathrm{mM}$ de $\mathrm{MgCl}_{2}, 2,5 \mu \mathrm{l}$ de lisado bacteriano, $2,5 \mu \mathrm{l}$ do tampão de reação e água miliQ esterilizada q.s.p. $25 \mu \mathrm{l}$. Com exceção do lisado, todos os componentes foram acrescentados a mistura em local asséptico. A amplificação foi feita em termociclador MJ Research.

Condições de amplificação. Baseadas em protocolo com modificações introduzidas por Johnson e O'Bryan (2000) que consistiram na incorporação de 
temperaturas de anelamento aumentadas e "touchdown" (TD) de $5 \stackrel{\circ}{\circ} \mathrm{em} 10$ ciclos. A temperatura de desnaturação preliminar foi de $94{ }^{\circ} \mathrm{C} / 2 \mathrm{~min}$, seguida pelo TD que iniciou com $94{ }^{\circ} \mathrm{C} / 30$ " e redução (rampagem) a $1,5{ }^{\circ} \mathrm{C} / \mathrm{s}$ até a temperatura de anelamento TD (que no primeiro ciclo foi $5{ }^{\circ} \mathrm{C}$ acima do plateau) e nos ciclos subsequentes foi reduzida a $0,5{ }^{\circ} \mathrm{C} /$ ciclo até retornar ao valor de plateau. Seguiu-se o anelamento por 1 minuto, rampagem a $0,1{ }^{\circ} \mathrm{C} / \mathrm{s}$ até $72{ }^{\circ} \mathrm{C}$ (temperatura de extensão) que foi mantida por 4,5 min. A fase plateau consistiu de 25 ciclos de desnaturação a $94{ }^{\circ} \mathrm{C} / 30 \mathrm{~s}$, rampagem a $1.5{ }^{\circ} \mathrm{C} / \mathrm{s}$ a temperatura de anelamento plateau, anelamento por $1 \mathrm{~min}$, rampagem a $0.1{ }^{\circ} \mathrm{C} / \mathrm{s}$ a $72{ }^{\circ} \mathrm{C}$ e extensão por $4.5 \mathrm{~min}$ a $72{ }^{\circ} \mathrm{C}$, seguida de uma extensão final de $72{ }^{\circ} \mathrm{C} / 1 \mathrm{~min}$.

Corrida eletroforética e análise do gel. O DNA amplificado foi separado por eletroforese $(5 \mathrm{~V} / \mathrm{cm})$ em agarose (Sigma) a $1 \%$. O gel foi tratado com solução de brometo de etídio a $0,5 \mu \mathrm{g} / \mathrm{ml}$, lavado e visualizado com auxílio de um software específico (Alpha Innotech Corporation, EUA) em um computador donectado a um capturador de imagens.

Análise dos dados. Feita com base na comparação dos perfis de bandas de DNA das amostras bacterianas gerados pela PCR e observados no gel.

\subsection{Detecção de marcadores genéticos de virulência}

As amostras de E. coli foram pesquisadas por PCR, para presença do plasmídio de a adesão agregativa (pAA) e os seguintes genes de virulência: aderência agregativa R (aggregative adherence R - aggR), E. coli attaching and effacing (eae), locus associado a invasão (invasion associated locus - ial), e antígeno plasmidial de invasão $\mathrm{H}$ (invasion plasmid antigen $\mathrm{H}-i p a H)$.

A mistura máster consistiu de $5 \mu \mathrm{l}$ de tampão de reação, 0,2 mM de dNTP, $0,15 \mathrm{mM}$ de $\mathrm{MgCl}_{2}, 0,2 \mathrm{mM}$ de cada um dos iniciadores, 0,7 unidades de TaqDNA polimerase, $5 \mu \mathrm{l}$ de lisado bacteriano e água miliQ esterilizada q.s.p. $50 \mu \mathrm{l}$. A mistura foi preparada observando-se os cuidados para evitar contaminação, conforme item anterior. Em todas as reações das amostras testes, foram incluídos tubos com lisados de amostras controles positivo e negativo, e um com todos os componentes 
da reação, exceto DNA. Os iniciadores utilizados, bem como as condições de PCR são mostrados na tabela 1.

As amostras amplificadas foram inicialmente misturadas a um tampão indicador da frente de corrida (tampão de amostra) e colocadas, em volumes de $5 \mu \mathrm{l}$, nas canaletas do gel ( $1 \%$ de agarose). Em uma das canaletas, foi aplicado DNA ladder 100 bp, como referência de tamanho molecular. Após a aplicação das amostras no gel, este foi submetido a uma corrente de $100 \mathrm{~V}$ em tempo suficiente para que a frente de corrida atingisse a extremidade oposta à das canaletas. Em seguida, o gel foi tratado com brometo de etídio e observado conforme exposto anteriormente.

\subsection{Análise estatística}

Diferenças entre os grupos foram calculadas pelo uso do teste de $\chi^{2}$. Em todos os resultados, o limite estatístico para significância foi um valor de $P<0.05$. 


\section{RESULTADOS}

\subsection{Densidade bacteriana e ERIC tipos}

Nas biópsias de todos os indivíduos investigados foram detectadas E. coli. Porém, a densidade bacteriana foi maior em pacientes com DIl do que no grupo controle: respectivamente, 95 colônias/35indivíduos e 35 colônias/19 indivíduos (média de 2,71 nos casos versus 1,89 nos controles) $(P<0,001)$. Todas as colônias identificadas e aqui designadas como amostras bacterianas, foram submetidas à tipagem por ERIC-PCR. Verificou-se que, em geral, amostras de um mesmo paciente apresentaram um mesmo perfil de bandas de DNA (fingerprint), quando submetidas ao ERIC-PCR, sugerindo tratar-se de um mesmo clone ou linhagem. Em uma das exceções, em um único paciente foram identificadas 5 amostras, 3 das quais apresentando um mesmo fingerprint e as outras duas um padrão comum, mas distinto das primeiras, indicando assim a presença de duas cepas distintas no mesmo paciente Por outro lado, em dois casos foram encontradas amostras com perfis idênticos em dois pacientes distintos. Porém, salvo estas exceções, de modo geral, os resultados de ERIC-PCR revelaram uma grande heterogeneidade entre as cepas identificadas na população bacteriana analisada (Dados não apresentados).

\subsection{Presença de sorogrupos 0 clássicos}

Um paciente controle apresentou 3 amostras pertencentes ao sorogrupo 0125, mas nenhum portador de DII apresentou amostras reativas com os soros específicos para os antígenos $O$ clássicos.

\subsection{Produção de hemolisina}

Amostras hemolíticas foram encontradas em 4 pacientes com DII $(11,4 \%)$ e 3 controles (15,8\%), uma diferença não significante estatisticamente $(P=0,21)$. 


\subsection{Adesão as células HEp-2}

Amostras aderentes a células HEp-2, expressas em ambos períodos do teste, foram encontradas em 30 pacientes com DII (85,7\%) e em 12 pacientes controles $(63,2 \%)$. A maior prevalência entre casos mostrou-se não significativa estatisticamente $(P>0,05)$. Porém, considerando-se o tempo de incubação, foi observada uma prevalência de aproximadamente o dobro de amostras que aderiram em $3 \mathrm{~h}$ em casos do que em controles $(83 \times 42 \%$, respectivamente, $P=0,01)$. A proporção de amostras expressando o padrão agregativo (figura 1a) foi ainda superior ( $P<0.02$,ver tabela 2). Por outro lado, amostras não aderentes (NA), aderentes difusamente em 3 e $6 \mathrm{~h}$ (AD3 e AD6, figura 1b) foram predominantes entre os pacientes controles (tabela 2).

\subsection{Relação genética entre amostras aderentes e não aderentes}

Com o objetivo de investigar possível relação de similaridade entre amostras expressando diferentes fenótipos de adesão em diferentes períodos do teste, um grupo de 10 amostras, representativo do total de cepas identificadas foi analisado através do programa MEGA (KUMAR; TAMURA; NEI, 2004), tendo por base os perfis de bandas de DNA obtidos através de ERIC-PCR. Os dados obtidos permitiram a construção do dendrograma apresentado na figura 2. Verificou-se que, independentemente do grupo de pacientes onde foram identificadas ou do padrão de adesão expresso, cepas aderentes em $6 \mathrm{~h}$ normalmente situaram-se próximo de cepas não aderentes, mas distantes em relação àquelas que aderiram no tempo de 3h. Estas últimas, em sua maioria, expressaram o padrão de adesão agregativo.

\subsection{Marcadores genéticos de virulência}

Entre os 5 marcadores investigados (eae, aggR e pAA, ial e ipaH), foram encontrados amostras positivas apenas para aggR, pAA e ipaH (figura 3). E estes foram detectados apenas em pacientes com RU: 3 pacientes apresentaram cepas positivas para aggR e pAA e outros 4, cepas positivas para eae.

\subsection{Invasibilidade}


Dados da literatura (DARFEUILLE-MICHAUD et al., 1998) sugerem que, amostras invasoras encontradas em pacientes com DIl são aquelas capazes de interagir com as células em testes de adesão utilizando-se D-manose. Por isto, submetemos ao teste de invasão apenas amostras aderentes (em 3h). No total, foram testadas 37 amostras, sendo 20 de pacientes com RU, 9 de pacientes com DC e 8 controles. A amostra HB101 (K12) apresentou um índice de invasão médio de $0,001 \%$. Deste modo, foram consideradas negativas amostras com valores iguais ou inferiores a este. Considerando-se este critério, foram detectadas 12 amostras invasoras, sendo 7 de pacientes com RU, 4 de pacientes controles e 1 de um paciente com DC. Não houve diferença estatisticamente significante entre os grupos. Entretanto, analisando os valores de invasibilidade, observa-se que amostras de pacientes com $\mathrm{RU}$ apresentaram os maiores índices. Uma destas amostras apresentou capacidade de invasão duas vezes maior que a de EIEC (Figura 4) 


\section{DISCUSSÃO}

A DII apresenta sintomas de um quadro infeccioso típico. Todavia, múltiplos fatores estão envolvidos e um número crescente de evidências tem assinalado a importância da microbiota intestinal (HENDRICKSON; GOKHALE; CHO, 2002). O intestino compreende o nicho mais diversificado e complexo do corpo humano e a grande maioria dos microrganismos a ele associados ainda não é conhecida (RHODES, 2007). Isto se deve em parte a impossibilidade de cultivá-los em condições artificiais. Assim, dada a sua abundância e facilidade de cultivo, as E. coli se tornaram um dos primeiros organismos da microbiota a ter seu envolvimento com a DII investigado. Em portadores da doença foi constatado um aumento na população destas bactérias (KOTLOWSKI et al., 2007). Porém a versatilidade de sua associação com o homem representa um desafio à compreensão deste achado. As bactérias excedentes podem corresponder a clones residentes ou linhagens patogênicas com um papel central no desenvolvimento dos sintomas. Uma das hipóteses considera que, como parte natural da microbiota intestinal, as E. coli seriam apenas fatores estimulatórios que desencadeariam uma resposta exagerada de um sistema imune defectivo. Assim, as bactérias seriam parte das conseqüências de uma anomalia pré-existente e não responsáveis diretos pela mesma. Em outra linha, muitos autores sustentam que a população de $E$. coli incluiria cepas dotadas de fatores de patogenicidade.

Embora não sendo um objetivo do trabalho atual e por isto não se empregou metodologia específica, foi observado um número maior de colônias de $E$. coli entre os isolados de biópsias de pacientes - um resultado que está de acordo com os dados da literatura (RHODES, 2007). Verificou-se, ainda, que na grande maioria dos casos, amostras de um mesmo paciente apresentaram um mesmo padrão de bandas na tipagem por ERIC-PCR, sugerindo a presença de um mesmo clone. $O$ ERIC-PCR tem sido objeto de críticas na literatura (MEACHAM et al., 2003) por gerar dados não reprodutíveis, entre outras razões, como função do surgimento de bandas espúrias. Em nossa experiência, também deparamos com esta limitação. A fim de minimizar a presença destas bandas, seguimos o protocolo de Johnson e O'Bryan (2000), onde as condições de amplificação são alteradas com a introdução 
de gradações (touchdown) nas temperaturas de anelamento. Conseguimos assim uma maior reprodutibilidade em diferentes amplificações.

A similaridade entre as cepas de um mesmo paciente, inferida pelos dados de ERIC-PCR, pôde também ser extrapolada com base na identidade dos fenótipos de adesão das bactérias. Em geral, amostras de um mesmo paciente ou foram uniformemente não aderentes ou expressaram um dos padrões identificados (AA ou AD)

Embora a prevalência de amostras aderentes fosse maior nos pacientes com DII, a diferença não se mostrou significativa estatisticamente. Porém, quando se considerou o fenótipo de adesão e o tempo necessário para sua expressão, notouse que amostras capazes de expressar o padrão AA em $3 \mathrm{~h}$ foram predominantes nos pacientes com DII. Este achado é de certo modo interessante porque pode explicar porque alguns autores (SCHULTSZ et al., 1997) não observaram diferenças na prevalência de $E$. coli enteroaderentes entre pacientes com DII e controles. Frequentemente, nestes trabalhos foi adotado um protocolo de 6h de incubação. Considerando-se a igual prevalência de amostras aderentes em ambos os grupos, observada por estes autores, o teste de 6h não pareceu distinguir amostras aderentes com e sem um possível envolvimento com a DII. Visando obter informações que pudessem auxiliar na compreensão desta questão, selecionamos aleatoriamente 10 amostras de E. coli de diferentes grupos e fenótipos de adesão, que foram submetidas à análise de similaridade genética, a partir dos dados de ERIC-PCR. O dendrograma gerado mostra que, independentemente do fenótipo de adesão ou do grupo de pacientes ao qual pertencem, amostras aderentes em 6h são mais semelhantes geneticamente às amostras não aderentes do que às amostras que aderem em $3 \mathrm{~h}$. Estes resultados reforçam a necessidade de se empregar o teste de 3h, para avaliar a adesão de E. coli isoladas de pacientes com DIl a células epiteliais cultivadas em laboratório.

Com relação à invasibilidade, de um total de 37 amostras ( 1 de cada paciente) testadas, apenas 12 apresentaram índice superior ao de E. coli K12, sendo 4 de 8 (50\%) em controles, 1 de 9 (11\%) em pacientes com DC e 7 de 20 (35\%) em pacientes com UC. Embora tenha havido uma maior prevalência de amostras invasoras entre controles, o índice médio de invasão de amostras de 
pacientes com RU foi superior $(0,0076 \times 0,0057)$, do que ao observado neste grupo. Em dois pacientes com RU foram encontradas amostras com invasibilidade superior àquela verificada para EIEC. Estes resultados são bastante distintos daquele obtido para pacientes com DC: neste grupo de pacientes foi encontrada apenas uma amostra invasora e que, ainda, apresentou o menor índice de invasão. Embora certo cuidado deva ser tomado na interpretação destes dados, tendo em vista o pequeno número estudado de pacientes com DC, eles revelam uma diferença em relação ao que é apresentado na literatura, onde as amostras destes pacientes são reconhecidas pela capacidade superior de invasão (DARFEUILLE-MICHAUD, 2002; SASAKI et al., 2007). Talvez esta divergência se justifique pelo modelo de células utilizadas no teste. Nestes trabalhos, foram empregadas linhagens de células intestinais, em geral polarizadas, enquanto que nós utilizamos células HEp-2, derivadas de carcinoma de laringe. Por outro lado, da mesma forma como apresentado nestes trabalhos, não identificamos amostras portadoras de ipaH e ial, que são marcadores tradicionais para a detecção de EIEC.

Além dos testes de adesão e invasão, as amostras foram analisadas quanto à capacidade de produção de hemolisina e presença de marcadores genéticos de patogenicidade.

A prevalência de amostras hemolíticas foi equivalente em casos e controles, indicando não ter qualquer associação desta característica com os sintomas de DII. Num trabalho clássico de 1974, Cooke et al. (1974) investigaram possível correlação da atividade de RU com a presença de amostras hemolíticas, concluindo não haver qualquer tipo de associação.

Embora um número reduzido de marcadores genéticos de virulência tenha sido investigado, trata-se de genes e plasmídios de referência para a diferenciação de EAEC (pAA e aggR), EIEC (ial e ipaH) e EHEC/EPEC (eae). Todas as amostras testadas foram negativas para os genes de EIEC e as amostras de pacientes com DC também não apresentaram quaisquer destes marcadores.

Dados da literatura parecem indicar que pelo menos algumas cepas de E. coli de pacientes com DC apresentam propriedades de virulência distintas daquelas de pacientes com $\mathrm{RU}$ e isto deve estar relacionado com as particularidades clínicas da 
doença. A formação de abscessos e de fístulas, sinais típicos da DC, são compatíveis com um patotipo invasor (RHODES, 2007). No estudo de DarfeuilleMichaud et al. (2004), enquanto que AIEC foi identificada na mucosa colônica de pacientes com DC, elas foram ausentes no sítio correspondente de pacientes com $\mathrm{RU}$. No trabalho atual, encontramos amostras invasoras apenas em pacientes com $\mathrm{RU}$ e, como já mencionado anteriormente, esta divergência pode ser explicada pelo modelo celular usado no teste. Todavia, assim como nestes trabalhos, não encontramos marcadores de virulência tradicionais de EIEC, o que excluiria a possibilidade de sua existência entre as $E$. coli estudadas.

Por outro lado, conjuntamente, eae e pAA/aggR e foram encontrados em $25,9 \%$ dos pacientes com RU. Todas estas cepas apresentaram o fenótipo AA e, com uma única exceção, foram aderentes em 3 h (dados não mostrados). O gene eae codifica a intimina, uma proteína de $94 \mathrm{KDa}$, presente na membrana externa e que é necessária para a associação íntima da bactéria com a célula hospedeira, através da ligação a um receptor produzido pela própria bactéria (KAPER; NATARO; MOBLEY, 2004). A intimina é determinante para a ocorrência de alterações no citoesqueleto hospedeiro, que leva às lesões conhecidas como "attaching and effacing" (A/E) e que podem ser desencadeadas por EPEC e EHEC. A EHEC têm sido considerada como o patotipo mais virulento de E. coli. Além da capacidade de induzir as lesões $A / E$, as EHEC são reconhecidas pela capacidade de produzir as citotoxinas de Shiga (Stx). O sítio de instalação no organismo (cólon) e outros aspectos de sua patogênese têm justificado a pesquisa de cepas produtoras de Stx (GIAFFER; HOLDSWORTH; DUERDEN, 1992) ou, pelos menos, portadoras dos genes correspondentes (KOTLOWSKI et al., 2007) em isolados de pacientes com DII. Todavia, os resultados têm se mostrado contraditórios (FARINA et al., 1995; GIAFFER; HOLDSWORTH; DUERDEN, 1992).

Um dos primeiros marcadores de diferenciação descritos de EAEC, o pAA é portador de múltiplos determinantes de virulência. O gene aggR, por sua vez, é um ativador transcricional de genes de virulência. Kaper; Nataro e Mobley (2004) propuseram o termo EAEC típica para designar cepas portadoras de aggR e dos genes de virulência por ele regulados. Fatores de virulência adicionais de EAEC incluem Pic, uma toxina com atividade de mucinase, Pet, uma enterotoxina com 
potencial para afetar o citoesqueleto e EAST-1, uma peptídeo-toxina pertencente à família das toxinas ST de ETEC. Pelo menos alguns destes fatores devem contribuir para a patogênese de EAEC que, embora não completamente conhecida, parece depender de ligação ao muco intestinal e formação de biofilme. Abundância de muco, particularmente na mucosa colônica, deve constituir-se num nicho favorável para a proliferação de EAEC numa condição em que a fisiologia intestinal está alterada (NAZLI et al., 2004), como é o caso da DII. A facilidade com a qual E. coli multiplica-se no cólon de pacientes com DII foi ilustrada em experimentos de remoção de muco, antes do cultivo das biópsias. Enquanto que nas biópsiascontroles não se observou qualquer crescimento bacteriano, nos tecidos de pacientes com DC, submetidos a idêntico tratamento, mais de $50 \%$ das bactérias facultativas cultivadas eram E. coli (MARTIN et al., 2004).

Tem sido também demonstrado que EAEC induzem produção de interleucina 8 (IL-8) pelas células intestinais (JIANG et al., 2002; STEINER et al., 1998). A IL-8 é conhecida como poderoso quimioatraente para leucócitos polimorfonucleares, cuja migração para a mucosa intestinal é uma marca típica dos sintomas de DIl. Os mecanismos de liberação de IL-8 parecem ser mediados pela interação da flagelina com TLR-5 (RHODES, 2007).

Embora não se saiba em que medida, o papel de $E$. coli na gênese ou complicação dos sintomas da DII gradativamente parece ficar claro. Como já discutido, a adesão a modelos celulares é uma característica comum destas bactérias. Nossos dados enfatizam a necessidade de se empregar testes com incubação de $3 \mathrm{~h}$, a fim de se distinguir cepas aparentemente dotadas de potenciais de virulência distintos, mas compartilhando um mesmo fenótipo de adesão. Além disto, os dados aqui apresentados sugerem que o fenótipo agregativo (que identifica EAEC) é a marca que distingue a população de $E$. coli que prolifera em pacientes com DII - tanto DC como RU. Finalmente, a presença de um grupo de genes de virulência clássicos apenas em cepas de pacientes com RU parece sugerir a associação de subgrupos distintos de EAEC com cada uma das variantes clínicas de DII. Sendo correta esta suposição, EAEC típicas estariam envolvidas com casos de $\mathrm{RU}$ e não de DC. Esta hipótese precisa ser testada em estudos futuros, os quais devem ser também direcionados a outras categorias patogênicas de E. coli. Por 
outro lado, considerando as características patológicas subjacentes à DII, tais como aumento na permeabilidade de mucosa e produção alterada de muco, pelo menos algumas das EAEC apresentadas aqui poderiam representar cepas comensais de $E$. coli, cuja migração para a região da submucosa poderia ser facilitada pela alteração nas condições locais. O fato de a grande maioria das amostras não reagir com os antissoros para os antígenos $O$ clássicos é um dado a favor de uma possível natureza comensal desta população bacteriana.

Apesar do grande número de número de prováveis fatores de virulência descritos para EAEC, seus mecanismos de patogenicidade ainda não são compreendidos. Assim que novas informações se tornarem disponíveis, o significado de seu aumento na mucosa colônica de pacientes com Dll deverá ser melhor entendido. 


\section{CONCLUSÕES}

- Pacientes com doença inflamatória intestinal apresentam aumento na população de Escherichia coli da mucosa retal. Com base nos dados de ERIC-PCR, esta população, em geral, parece ser formada por uma única linhagem ou clone.

- Não se observou similaridade genética entre amostras de diferentes pacientes, através da análise por ERIC-PCR, o que sugere que não deve haver um patotipo único associado à doença ou que a população aumentada constitui-se de representantes comensais.

- Apesar de serem capazes de aderir a células HEp-2, se algumas destas amostras tiverem qualquer envolvimento com a etiologia ou complicação dos sintomas da doença, elas serão restritas ao grupo que adere em $3 \mathrm{~h}$ de contato com as células.

- Estas amostras expressam o padrão agregativo e pertencem, portanto, a EAEC, uma categoria heterogênea, que inclui cepas comensais e patogênicas. Estudos adicionais serão necessários para avaliar o significado de sua presença na mucosa dos pacientes aqui estudados.

- A grande maioria das amostras não pertence ao sorogupos $O$ clássicos de $E$. coli (que tradicionalmente identificava EPEC), o que dá suporte à condição de comensais para estas bactérias. 
Tabela 1. Marcadores genéticos de virulência, primers, tamanho das seqüências amplificadas e condições da PCR.

\begin{tabular}{|c|c|c|c|c|c|c|c|}
\hline \multirow[t]{2}{*}{ Marcador $\underline{\underline{a}}$} & \multirow[t]{2}{*}{ Primers (5'-3') } & \multirow{2}{*}{$\begin{array}{c}\text { Tamanho } \\
\text { da } \\
\text { seqüência }\end{array}$} & \multicolumn{4}{|c|}{ Condições de amplificação } & \multirow[t]{2}{*}{ Referência } \\
\hline & & & Desnaturação & Anelamento & Extensão & $\begin{array}{c}\text { № } \\
\text { ciclos }\end{array}$ & \\
\hline \multirow[t]{2}{*}{ eae } & 1-ACGTTGCAGCATGGGTAACTC & 815 & $94^{\circ} \mathrm{C} / 1^{\prime}$ & $56 \% / 2$ & $72^{\circ} \mathrm{C} / 1^{\prime}$ & 29 & (Gannon, et \\
\hline & 2-GATCGGCAACAGTTTCACCTG & & & & & & al., 1993) \\
\hline \multirow[t]{2}{*}{ pAA } & 1-CTGGCCAAAGACTGTATCAT & 630 & $94^{\circ} \mathrm{C} / 40^{\prime \prime}$ & $53^{\circ} \mathrm{C} / 1^{\prime}$ & $72^{\circ} \mathrm{C} / 1^{\prime}$ & 29 & (Schimidt, et \\
\hline & 2-CAATGTATAGAAATCCGCTGTT & & & & & & al., 1995) \\
\hline \multirow[t]{2}{*}{$\operatorname{agg} R$} & 1-GTATACACAAAAGAAGGAAGC & 254 & $95 \%$ & $52^{\circ} \mathrm{C} / 1^{\prime}$ & $72^{\circ} \mathrm{C} / 1^{\prime}$ & 30 & (Toma, et \\
\hline & 2-ACAGAATCGTCAGCATCAGC & & & & & & al., 2003) \\
\hline \multirow[t]{2}{*}{ ipaH } & 1-GTATACACAAAAGAAGGAAGC & 619 & $95 \%$ & $52^{\circ} \mathrm{C} / 1^{\prime}$ & $72^{\circ} \mathrm{C} / 1^{\prime}$ & 30 & (Toma, et \\
\hline & 2-GCCGGTCAGCCACCCTCTGAGGTAC & & & & & & al., 2003) \\
\hline \multirow[t]{2}{*}{ ial } & 1-CTGGATGGTATGGTGAGG & 320 & $94^{\circ} \mathrm{C} / 1^{\prime}$ & $43^{\circ} \mathrm{C} / 2^{\prime}$ & $72^{\circ} \mathrm{C} / 3^{\prime}$ & 25 & (Frankel, et \\
\hline & 2-GGAGGCCAACAATTATTTCC & & & & & & al., 1990) \\
\hline
\end{tabular}

a Marcadores genéticos de virulência: eae $=E$. coli "attaching and effacing", pAA= plasmídio de adesão agregativa, aggR= "aggregative adhesion R", ipaH=" invasion plasmid antigen H", ial= "invasion associated locus". 


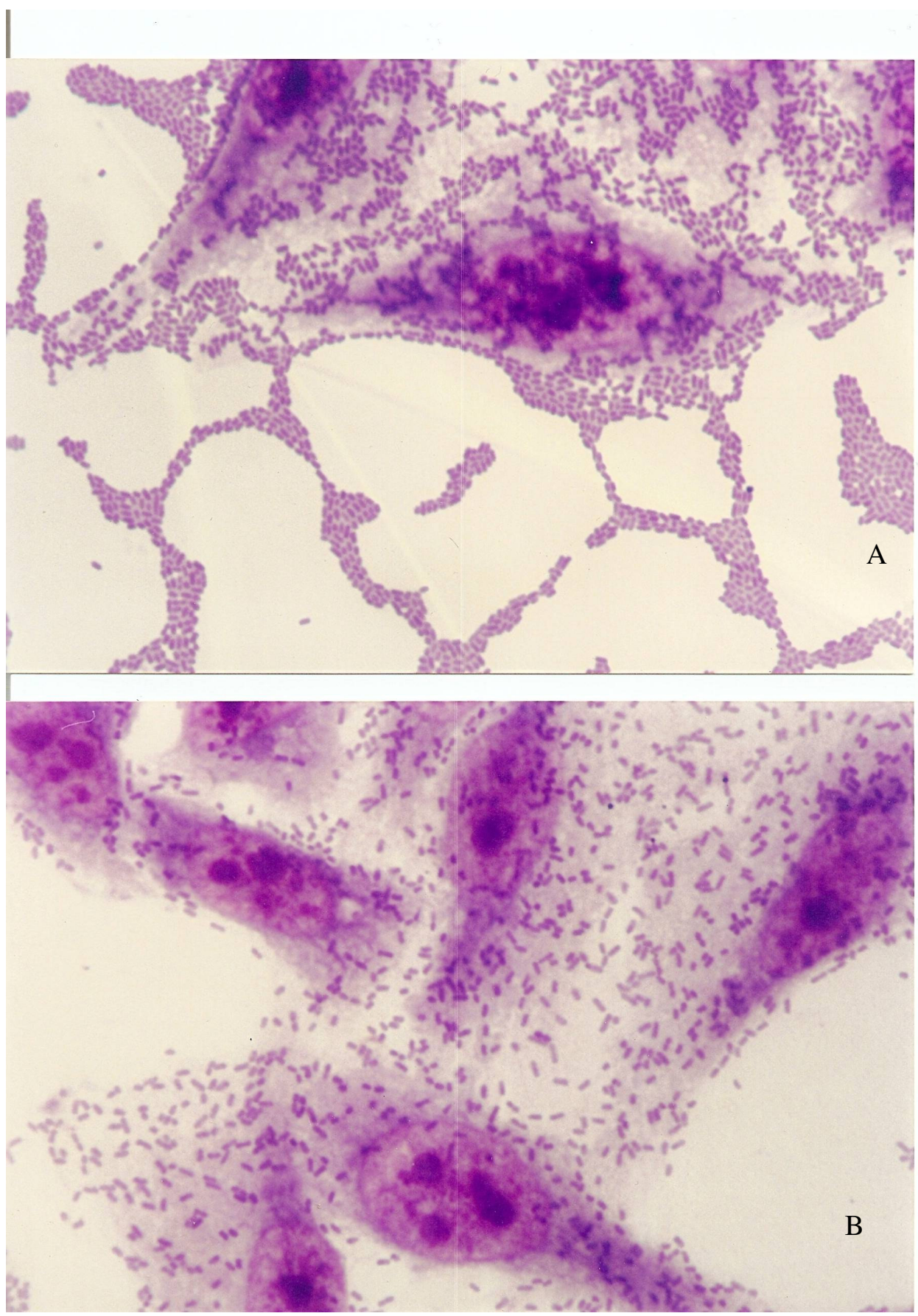

Figura 1. Padrões de adesão de Escherichia coli isoladas de pacientes com doença inflamatória intestinal. A- adesão agregativa. B- adesão difusa. Período de incubação $=3 \mathrm{~h}$. Aumento $=1000 x$. Coloração: May Grünwald. 
Tabela 2.Número (\%) de indivíduos nos quais foram isoladas amostras de E. coli não aderentes (NA) e amostras apresentando padrões ou fenótipos de adesão típícos a células HEp-2.

\begin{tabular}{llll}
\hline \multicolumn{1}{c}{ Fenótipos de } & & \\
adesão* & Casos & Controles & Total \\
\hline AA3 & $25(71.4)$ & $5(26.3)$ & 30 \\
AA6 & $1(2.8)$ & $2(10.5)$ & 3 \\
AD3 & $4(11.4)$ & $3(15.8)$ & 7 \\
AD6 & 0 & $2(10.5)$ & 2 \\
NA & $5(14.3)$ & $7(36.8)$ & 12 \\
& & & 54 \\
\hline Total & 35 & 19 & \\
\hline
\end{tabular}

* Fenótipos de adesão: $A A$ e $A D$, respectivamente adesão agregativa e difusa, expressas em 3 ou $6 \mathrm{~h}$ de contato com as células. 

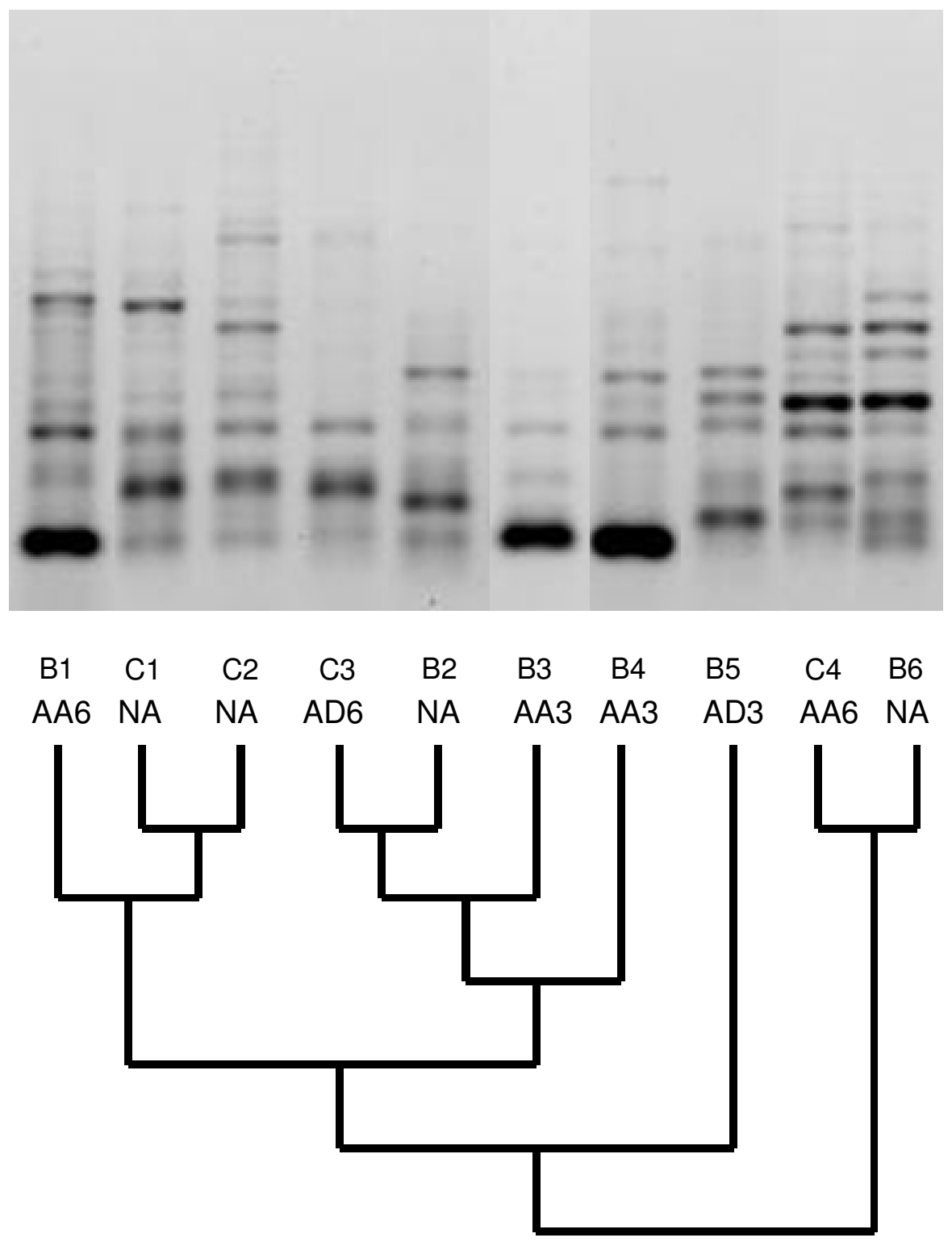

Figura 2. Dendrograma da relação genética entre 10 amostras de $E$. coli de diferentes fenótipos de adesão e respectivos padrões de bandas (fingerprints) obtidos por ERIC-PCR. As amostras de pacientes com DII estão identificadas com a letra B e, as dos controles, com a letra C. Os fenótipos de adesão (para legenda, ver tabela 2) são indicados abaixo das letras. 


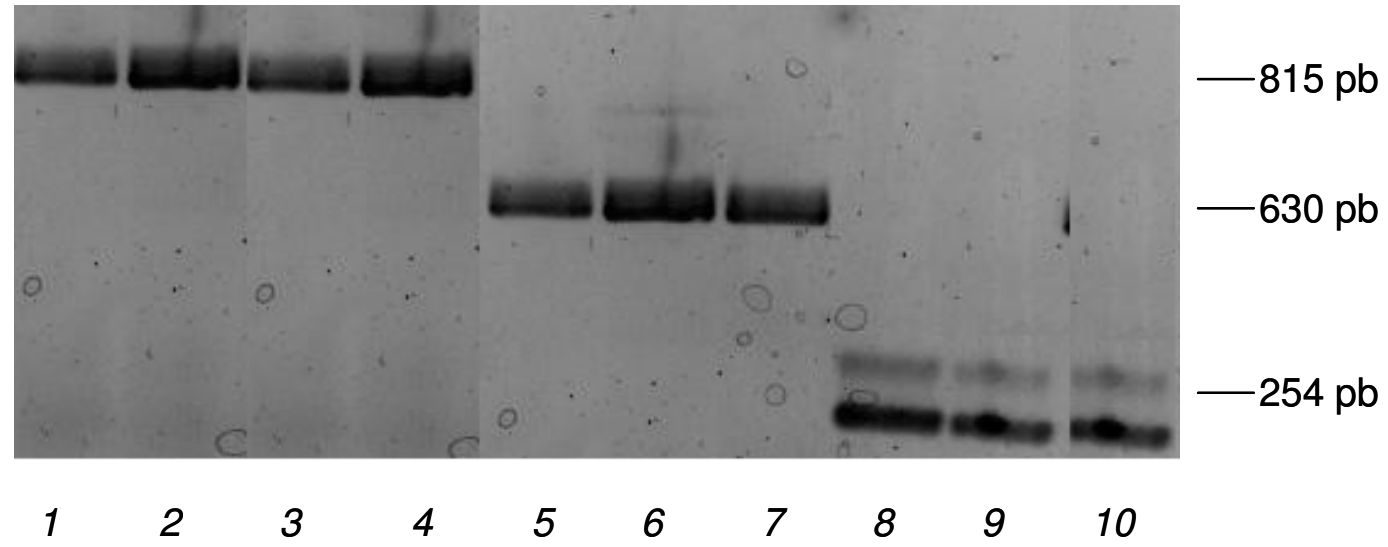

Figura 3. Gel de agarose com produtos de PCR, utilizando-se primers específicos para eae, pAA e aggR. Amostras 1-4, eae+; 5-7, pAA+ e 8-10, aggR+. As E. coli de referência E2348/69, 17-2 e O42 foram utilizadas como controles positivos, respectivamente para eae, $p A A$ e aggR. 
Figura 4. Invasibilidade das amostras de E. coli isoladas de Pacientes com doença inflamatória intestinal.

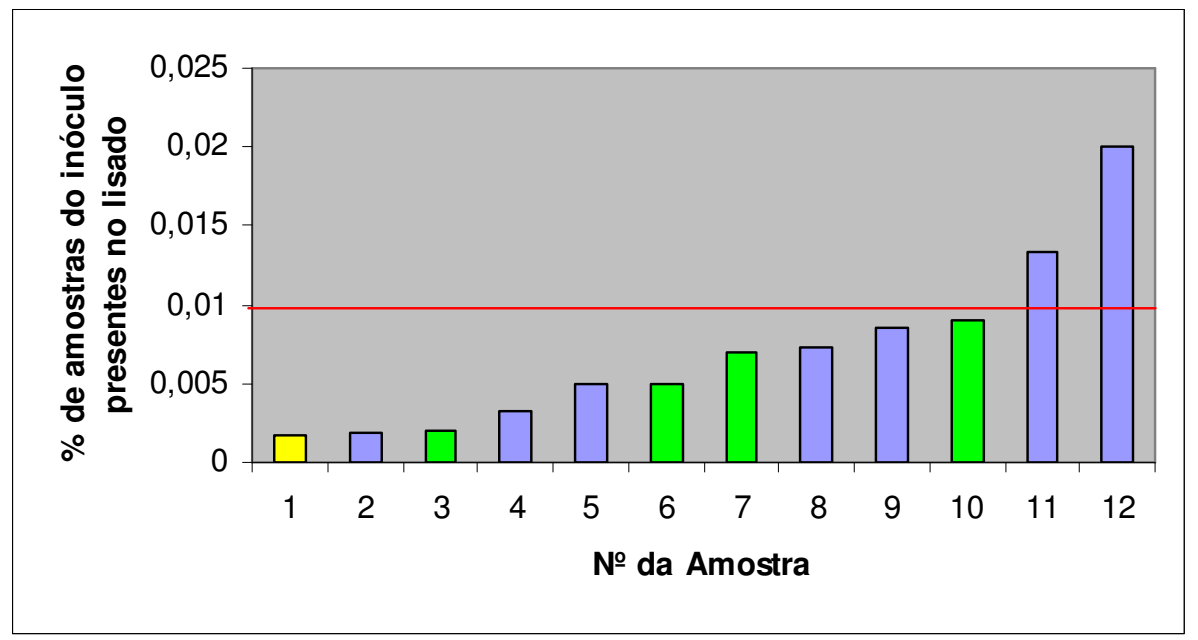

\section{Legenda}

口 Controles

Retocolite ulcerativa

口 Doença de Crohn

A linha vermelha marca a \% de invasibilidade de EIEC 


\section{REFERÊNCIAS BIBLIOGRÁFICAS}

ANDUS, T.; GROSS, V. Etiology and pathophysiology of inflammatory bowel disease - Environmental factors. Hepato-Gastroenterol., v. 47, p. 29-43, 2000.

ARULAMPALAM, V.; GREICIUS, G.; PETTERSSON, S. The long and winding road to gut homeostasis. Curr. Opin. Gastroenterol., v. 22, p. 349353, 2006.

BARNICH, N.; DARFEUILLE-MICHAUD, A. Role of bacteria in the etiopathogenesis of inflammatory bowel disease. World J. Gastroenterol., v.13, p. 5571-5576, 2007.

BOUDEAU, J.; GLASSER, A. L.; MASSERET, E.; JOLY, B.; DARFEUILLEMICHAUD, A. Invasive Ability of an Escherichia coli strain isolated from the ileal mucosa of a patient with Crohn's disease. Infect. Immun., v. 67, p. 4499-4509, 1999.

CAMPIERI, M.; GIONCHETTI, P. Bacteria as the cause of ulcerative colitis. Gut, v. 48, p. 132-135, 2001.

COOKE, E. M.; EWINS, S. P.; HYWEL-JONES, J.; LENNARD-JONES, J. E. Properties of strains of Escherichia coli carried in different phases of ulcerative colitis. Gut, v. 21, p. 143-146, 1974.

DARFEUILLE-MICHAUD, A. Adherent-invasive Escherichia coli: a putative new E. coli pathotype associated with Crohn's disease. Int. J. Med. Microbiol., v. 292, p. 185-193, 2002. 
DARFEUILLE-MICHAUD, A.; BOUDEAU, J.; BULOIS, P.; NEUT, C.; GLASSER, A. L.; BARNICH, N.; BRINGER, M. A.; SWIDSINKI, A.; EAUGERIE, L.; COLOMBEL, J. F. High prevalence of adherent-invasive Escherichia coli associated with ileal mucosa in Crohn's disease. Gastroenterol., v. 127, p. 412-421, 2004.

DARFEUILLE-MICHAUD, A.; NEUT, C.; BARNICH, N.; LEDERMAN, E.; DI MARTINO, P.; DESREUMAUX, P.; GAMBIEZ, L.; JOLY, B.; CORTOT, A.; COLOMBEL, J. Presence of adherent Escherichia coli strains in ileal mucosa of patients with Crohn's disease. Gastroenterol., v. 115, p. 14051413, 1998.

DUCHMANN, R.; MAY, E.; HEIKE, M.; KNOLLE, P.; NEURATH, M.; MEYER ZUM BUSCHENFELDE, K. H. T cell specificity and cross reactivity towards enterobacteria, Bacteroides, Bifidobacterium , and antigens from resident intestinal flora in humans. Gut, v. 44, p. 812-818, 1999.

FARINA, C.; CAPRIOLI, A; LUZZI, I.; SONZOGNI, A.; GOGLIO, A. Ulcerative colitis precipitated by a verocytotoxin-producing Escherichia coli infection. Ital. J. Gastroenterol., v. 27, p. 498-500, 1995.

FIOCCHI, C. The multiple components of inflammatory bowel disease pathogenesis: should we invest in all of them or should we pick and choose? Curr. Opin. Gastroenterol., v. 21, p. 399-400, 2005.

FRANKEL, G.; RILEY, L.; GIRON, J. A.; VALMASSOI, J.; FRIEDMANN, A.; STROCKBINE, N.; FALKOW, S.; SCHOOLNIK, G. K. Detection of Shigella in feces using DNA amplification. J. Infect. Dis., v. 161, p. 1252-1256, 1990.

GANNON, V. P. J.; RASHED, M.; KING, R. K.; THOMAS, E. J. Detection and characterization of the eae gene of Shiga-like toxin-producing 
Escherichia coli using the polymerase chain reaction. J. Clin. Microbiol., v. 31, p. 1268-1274, 1993.

GIAFFER, M. H.; HOLDSWORTH, C. D.; DUERDEN, B. I. Virulence properties of Escherichia coli strains isolated from patients with inflammatory bowel disease. Gut, v. 33, p. 646-650, 1992.

GIONCHETTI, P.; RIZZELLO, F.; CAMPIERI, M. Probiotics and antibiotcs in inflammatory bowel disease. Curr. Opin. Gastroenterol., v. 17, p. 331-335, 2001.

GORDON, J. N.; SABATINO, A.; MACDONALD, T. T. The pathophysiologic rationale for biological therapies in inflammatory bowel disease. Curr. Opin. Gastroenterol., v. 21, p. 431-437, 2005.

GUARNER, F. C. The intestinal flora in inflammatory bowel disease: normal or abnormal. Curr. Opin. Gasatroenterol., v. 21, p. 414-418, 2005.

HART, A. L.; STAGG, A. J.; FRAME, M.; GRAFFNER, H.; GLISE, H.; FALK, P.; KAMM, M. A. Review article: the role of the gut flora in health and disease, and its modification as therapy. Aliment. Pharmacol. Ther., v. 16, p. 1383-1393, 2002.

HENDRICKSON, B. A.; GOKHALE, R.; CHO, J. H. Clinical aspects and pathophysiology of inflammatory bowel disease. Clin. Microbiol. Rev., v. 15, p. 79-94, 2002.

HOOPER, L. V. Bacterial contributions to mammalian gut development. TRENDS Microbiol., v. 12, p. 129-134, 2004. 
JASKOWSKI, T. D.; LITWIN, C. M.; HILL, H. R. Analysis of serum antibodies in patients suspected of having inflammatory bowel disease. Clin. Vaccine Immunol., v. 13, p. 655-660, 2006.

JIANG, Z. D.; GREENBERG, D.; NATARO, J. P.; STEFFEN, R.; DUPONT, $\mathrm{H}$. L. Rate of occurrence and pathogenic effect of enteroaggregative Escherichia coli virulence factors in international travelers. J. Clin. Microbiol., v. 40, p. 4185-4190, 2002.

JOHNSON, J. R.; O' BRYAN. T. Improved repetitive element PCR fingerprinting for resolving pathogenic and nonpathogenic phylogenetic groups within Escherichia coli . Clin. Diagn. Lab. Immunol., v. 7, p. 265$273,2000$.

KAPER, J. B.; NATARO, J. P.; MOBLEY, H. L. T. Pathogenic Escherichia coli . Nat. Rev., v. 2, p.123-140, 2004.

KOTLOWSKI, R.; BERNSTEIN, C. N.; SEPEHRI, S.; KRAUSE, D. O. High prevalence of Escherichia coli belonging to the B2+D phylogenetic group in inflamamatory bowel disease. Gut, v. 56, p. 669-675, 2007.

KRUIS, P. F.; POKROTNIEKS, J.; LUKAS, M.; FIXA, B.; KASCAK, M.; KAMM, M. A.; WEISMUELLER, J.; BEGLINGER, C.; STOLTE, M.; WOLFF, C.; SCHULZE, J. Maintaining remission of ulcerative colitis with the probiotic Escherichia coli Nissle 1917 is as effective as as with standard mesalazine. Gut, v. 53, p.1617-1623, 2004.

KUMAR, S.; TAMURA, K.; NEI, M. MEGA3: Integrated software for Molecular Evolutionary Genetics Analysis and sequence alignment. Brief. Bioinf., v. 5, p.150-163, 2004.

LAKATOS, P. L.; FISCHER, S.; LAKATOS, L.; GAL, I.; PAPP, J. Current concept on the pathogenesis of inflammatory bowel disease-crosstalk between genetic and microbial factors: Pathogenic bactéria and altered bacterial sensing or changes in mucosal integrity take "tool"? World J. Gastroenterol., v. 12, p. 1829-1841, 2006. 
MARTIN, H. M.; CAMPBELL, B. J.; HART, C. A.; MPOFU, C.; NAYAR, M.; SINGH, R.; ENGLYST, H.; WILLIAMS, H. F.; RHODES, J. M. Enhanced Escherichia coli adherence and invasion in Crohn's disease and colon cancer. Gastroenterol., v. 127, p. 80-93, 2004.

MASSERET, E.; BOUDEAU, J.; COLOMBEL, J. F.; NEUT, C.; DESREUMAUX, P.; JOLY, B.; CORTOT, A.; DARFEUILLE-MICHAUD, A. Genetically related Escherichi coli strains associated with Crohn's disease. Gut, v. 48, p. 320-325, 2001.

MATSUDA, H.; FUGIYAMA, Y.; ANDOH, A. Characterisation of antibody responses against rectal mucosa-associated bacterial flora in patients with ulcerative colitis. J. Gastroent. Hepatol., v. 15, p. 61-68, 2000.

MEACHAM, K. J.; ZHANG, L.; FOXMAN, B.; BAUER, R. J.; MARRS, C. F. Evaluation of genotyping large numbers of Escherichia coli isolates by enterobacterial repetitive intergenic consensus PCR. J. Clin. Microbiol., v. 41, p. 5224-5226, 2003.

MONTEIRO, E. Ciclosporina no tratamento da colite ulcerosa grave refractária: será a melhor solução para a maioria destes doentes? GE Editorial, v. 12, p. 294-295, 2005.

MYLONAKI, M.; RAYMENT, N. B.; RAMPTON, D. S.; HUDSPIPTH, B. N.; BROSTOFF, J. Molecular characterization of rectal mucosa-associated bacterial flora in inflammatory bowel disease. Inflamm. Bowel Dis., v. 11, p. 481-487, 2005.

NATARO, J. P.; KAPER, J. B. Diarrheagenic Escherichia coli . Clin. Microbiol. Rev., v.11, p.142-201, 1998.

NAZLI, A.; YANG, P. C.; JURY, J.; HOWE, K.; WATSON, J. L.; SODERHOLM, J. D.; SHERMAN, P. M.; PERDUE, M. H.; MCKAY, D. M. 
Epithelia under metabolic stress perceive commensal bacteria as a threat. Am. J. Pathol., v. 164, p. 947-957, 2004.

NEWMAN, B.; SIMINOVITCH, K. A. Recent advances in the gentetics of inflammatory bowel disease. Curr. Opin. Gastroenterol., v. 21, p. 401-407, 2005.

NOVERR, M. C.; HUFFNAGLE, G. B. Does the microbiota regulate immune responses outside the gut? TRENDS Microbiol., v. 12, p. 562-567, 2004.

RHODES, J. M. The role of Escherichia coli in inflammatory bowel disease. Gut, v. 56, p. 610-612, 2007.

SASAKI, M.; SITARAMAN, S. V.; BABBIN, B. A.; GERNER-SMIDT, P.; RIBOT, E. M.; GARRET, N.; ALPERN, J. A.; ALKYILDIZ, A.; THEISS, A. L.; NUSRAT, A.; KLAPPROTH, J. Invasive Escherichia coli are a feature of Crohn's disease. Labor. Invest., p.1-13, 2007.

SCHIMIDT, H.; KNOP, C.; FRANKE, S.; ALEKSIC, S.; HEESEMANN, J.; $\mathrm{KARCH}, \mathrm{H}$. Development of PCR for screening of enteroaggregative Escherichia coli . J. Infect. Dis., v. 33, p. 701-705, 1995.

SCHULTSZ, C.; MOUSSA, M.; VAN KETEL, R.; TYTGAT, G. N. J.; DANKERT, J. Frequency of pathogenic and enteroadherent Escherichia coli in patients with inflamatory bowel disease and controls. J. Clin. Pathol., v. 50, p. 573-579, 1997.

SEKSIK, P.; RIGOTTIER-GOIS, L.; GRAMET, G.; SUTREN, M.; POCHART, P.; MARTEAU, P.; JIAN, R.; DOER, J. Alterations of the dominant faecal bacterial groups in patients with Crohn's disease of the colon. Gut, v. 52, p.237-242, 2003.

SITARMAN, V. S.; KLAPPROTH, J. M.; MOORE, D. A.; LANDERS, C.; TARGAN, S.; WILLIAMS, I. R.; GEWIRTZ, A. T. Elevated flagellin-specific 
immunoglobulins in Crohn's disease. Am. J. Physiol. Gastrointest. Liver Physiol., v. 288, p.403-406, 2005.

STEINER, T. S.; LIMA, A. A. M.; NATARO, J. P.; GUERRANT, R. L. Enteroaggregative Escherichia coli produce intestinal inflammation and growth impairment and cause interleukin-8 release from intestinal epithelial cells. J. Infect. Dis., v. 177, p.88-96, 1998.

STROBER, W.; FUSS, I.; MANNON, P. The fundamental basis of inflammatory bowel disease. J. Clin. Invest., v. 17, p. 514-521, 2007.

TOMA, C.; LU, Y.; HIGA, N.; NAKASONE, N.; CHINEN, I.; BASCHKIER, A.; RIVAS, M.; IWANAGA, M. Multiplex PCR assay for identification of human diarrheagenic Escherichia coli . J. Clin. Microbiol., v. 41, p. 2669-2671, 2003.

VAN DER WIEL-KORSTANJE, J. A. A.; WINKLER, K. C. The faecal flora in ulcerative colitis. J. Med. Microbiol., v. 8, p. 491-501, 1975.

WORLD HEALTH ORGANIZATION. Programme for control of diarrhoeal diseases. Manual for laboratory investigations of acute enteric infections. Geneva: WHO, 1987.

WHELAN, G. Clinicas Médicas da América do Norte. Rio de Janeiro: R. G. Farmer, 1990. Cap. 1, p. 1-13. Epidemiologia da doença inflamatória intestinal. 